\title{
Study on Effect of Different Weaning System on Carcass Characteristics of Tellicherry Goat
}

\author{
T. Geetha ${ }^{1 *}$, P. Tensingh Gnanaraj ${ }^{2}$, U. Lakshmikantan ${ }^{1}$, \\ R. Mathivanan ${ }^{1}$ and S. Manokaran ${ }^{3}$
}

${ }^{I}$ Veterinery University Training and Research Centre, Tamil Nadu Veterinary and Animal Sciences University, Veterinary Hospital campus, Kamarajarsalai, Tirpur-641 604, Tamil Nadu, India

${ }^{2}$ Tamil Nadu Veterinery and Animal Sciences University, Madavaram Milk Colony, Chennai-51, India

${ }^{3}$ Kangayam Cattle Research Station, Uppupallam, Baguthampalayam, Sathyamangalam - 638451 , India

*Corresponding author

\section{A B S T R A C T}

\section{Keywords}

Tellichery Kid, Weaning, Dressing percentage, Carcass traits

\section{Article Info}

Accepted: 05 April 2020 Available Online: 10 May 2020
To study the effect of different weaning systems on carcass traits of Tellicherry goats 42 Tellicherry kids were allocated to three treatment groups viz. Group 1Late weaning (at three month); Group 2- Mid weaning (at two month) and Group 3- Early weaning (at one month). Different weaning system had non-significant ( $p>0.05$ ) effect on pre-slaughter weight, empty live body weight, carcass weight, dressing percentage and carcass length. Dressing percentage in Tellichery goat was $38.66 \pm 0.66 \%$ irrespective of weaning system. Leg portion $(33.53 \pm 0.66 \%)$ contributed the highest proportion followed by breast and shank, rack, neck, shoulder, loin and flank. There was no significant difference $(p>0.05)$ between treatments in weight of edible and non-edible offals. Among non-edible offal, hide had the highest proportion $(8.78 \pm 0.31 \%)$ on pre-slaughter weight basis.

\section{Introduction}

Weaning is commonly practiced in large sized goat farms. Generally kids are weaned at 3-4 months of age in Indian condition. Kids are also weaned at 60 days in other countries (Memisi et al., 2009). Early weaning helps in saving the milk, favours early resumption of ovarian activity and early development of kid's rumen. However, weaning at 45 and 60 days has no influence on growth characteristics. Such early weaning of kids but might have an effect on growth performance, weight at slaughter and on 
certain carcass traits. Although, literature on effect of weaning age on carcass traits in sheep are available (Hashem et al., 2013), direct references in this area for goats are very scanty. Considering aforesaid facts the present study was conducted to compare the carcass characteristics of Tellichery goat under three different systems of weaning.

\section{Materials and Methods}

The study was conducted at Instructional Livestock Farm Complex, TANUVAS, Madhavaram Milk Colony during the period from March- 2017 to May- 2018. A total of 30 male kids were allocated to three treatment groups. Group 1: Late weaning $(n=10)$, Kids remained with the dam for 3 month and subsequently weaned. Group 2: Mid weaning $(n=10)$, Kids weaned on completion of the 2 month. Group 3: Early weaning $(n=10)$ : Kids remained with the dam for 1 month and subsequently weaned. Under each treatment, weaned kids were kept in group of 2-3 depending on number of kids to make replicate.

The pens were with a pucca floor and attached open paddock. Four animals from each group were randomly selected and slaughtered by Halal method at the age of 11 to 12 month. The body weights were recorded before slaughtering. After bleeding, each carcass was dressed, and all parameters were recorded as per standard protocol. The data was pooled and analysed as per standard statistical procedure (Snedecor and Cochran, 1994).

\section{Results and Discussion}

The results (Table 1) showed that different weaning system has non-significant $(p>0.05)$ effect on different carcass traits. Average preslaughter body weights in Gr 1, Gr 2 and Gr 3 were $16.34 \pm 0.39,16.57 \pm 1.41,17.31 \pm 1.23 \mathrm{~kg}$, respectively. Carcass weight in $\mathrm{Gr} 1, \mathrm{Gr} 2$ and Gr 3 were $6.34 \pm 0.28,6.51 \pm 0.72,6.96 \pm 0.56$ $\mathrm{kg}$ respectively which were non-significantly ( $>0.05$ ) affected by weaning systems. Our results are in agreement with previous report (Huiling et al., 2019; Ugur et al., 2004) concluding that weaning at 45 and 60 days had no influence on growth characteristics of kids.

Contradictory to present study, Nagpala et al., (1995) reported that early weaned kids had lower pre-slaughter weight and carcass weight as compared with late weaned kids. Irrespective of weaning system average carcass weight in our study $(6.60 \pm 0.30 \mathrm{~kg})$ was found higher than reported in Black Bengal goat (Singh et al., 1994).

Dressing percentage (slaughter weight basis) in Tellicherry goat was found $38.66 \pm 0.66 \%$ irrespective of weaning system. This value is closer to the reports in Osmanabadi goat (Hakim et al., 2005). While it is lower than reported in Barbari goat (Das et al., 2011) and Sirohi goat (Sureshkumar et al., 2010). This might be due to the higher pre-slaughter weight reported in these breeds compared to Tellicherry goat. Drzaic et al., (2011) suggested that, kids having higher slaughter weight had higher carcass weight and higher weight of internal organs than kids of smaller slaughter weight.

The yield of primal cuts including legs, loin, rack, neck, shoulder, flank and breast and shank did not differ significantly $(p>0.05)$ with the weaning systems. Irrespective of groups among the primal cuts, the leg portion $(33.53 \pm 0.66 \%)$ contributed the highest proportion followed by breast and shank $(22.95 \pm 0.58 \%)$, rack $(13.26 \pm 0.74 \%)$, neck $(10.43 \pm 0.37 \%)$, shoulder $(8.64 \pm 0.31 \%)$, loin $(7.75 \pm 0.21 \%)$ and flank $(3.42 \pm 0.29 \%)$. This is in agreement with previous reports in goat (Elangovan et al., 2010). 
Table.1 Carcass traits $(\mathrm{Mean} \pm \mathrm{SE})$ in Tellicherry goat under different weaning systems

\begin{tabular}{|c|c|c|c|c|}
\hline Parameters & Group 1 & Group 2 & Group 3 & Over all \\
\hline \multicolumn{5}{|c|}{ Carcass weight and dressing percentage } \\
\hline Pre-slaughter weight (kg) & $16.34 \pm 0.39$ & $16.57 \pm 1.41$ & $17.31 \pm 1.23$ & $16.74 \pm 0.59$ \\
\hline Empty body weight (kg) & $12.83 \pm 0.24$ & $13.69 \pm 1.16$ & $14.15 \pm 0.90$ & $13.56 \pm 0.47$ \\
\hline Carcass weight (kg) & $6.34 \pm 0.28$ & $6.51 \pm 0.72$ & $6.96 \pm 0.56$ & $6.60 \pm 0.30$ \\
\hline Carcass length $(\mathrm{cm})$ & $55.29 \pm 0.47$ & $56.31 \pm 1.65$ & $57.80 \pm 1.44$ & $56.46 \pm 0.76$ \\
\hline Dressing \% (SWB)* & $37.82 \pm 1.40$ & $38.54 \pm 1.32$ & $39.62 \pm 0.81$ & $38.66 \pm 0.66$ \\
\hline Dressing \% (EWB) & $48.81 \pm 1.51$ & $48.93 \pm 2.72$ & $49.67 \pm 1.81$ & $49.13 \pm 1.10$ \\
\hline \multicolumn{5}{|c|}{ Primal Cuts weight (Proportion of pre-slaughter weight basis) } \\
\hline Leg weight (kg) & $\begin{array}{c}2.10 \pm 0.01 \\
(33.65 \pm 1.52 \%)\end{array}$ & $\begin{array}{c}2.24 \pm 0.17 \\
(32.99 \pm 1.18 \%)\end{array}$ & $\begin{array}{c}2.41 \pm 0.18 \\
(33.99 \pm 0.80 \%)\end{array}$ & $\begin{array}{c}2.25 \pm 0.08 \\
(33.53 \pm 0.66 \%)\end{array}$ \\
\hline Loin weight (kg) & $\begin{array}{c}0.47 \pm 0.03 \\
(7.53 \pm 0.36 \%)\end{array}$ & $\begin{array}{c}0.52 \pm 0.06 \\
(7.66 \pm 0.30 \%)\end{array}$ & $\begin{array}{c}0.57 \pm 0.05 \\
(8.04 \pm 0.24 \%)\end{array}$ & $\begin{array}{c}0.52 \pm 0.03 \\
(7.75 \pm 0.21 \%)\end{array}$ \\
\hline Neck weight $(\mathbf{k g})$ & $\begin{array}{c}0.60 \pm 0.05 \\
(9.61 \pm 0.48 \%)\end{array}$ & $\begin{array}{c}0.71 \pm 0.10 \\
(10.45 \pm 0.55 \%)\end{array}$ & $\begin{array}{c}0.78 \pm 0.07 \\
(11.0 \pm 0.91 \%)\end{array}$ & $\begin{array}{c}0.70 \pm 0.04 \\
(10.43 \pm 0.37 \%)\end{array}$ \\
\hline Rack weight (kg) & $\begin{array}{c}0.78 \pm 0.15 \\
(12.5 \pm 2.13 \%)\end{array}$ & $\begin{array}{c}0.97 \pm 0.13 \\
(14.28 \pm 0.52 \%)\end{array}$ & $\begin{array}{c}0.91 \pm 0.08 \\
(12.83 \pm 0.57 \%)\end{array}$ & $\begin{array}{c}0.89 \pm 0.06 \\
(13.26 \pm 0.74 \%)\end{array}$ \\
\hline Shoulder weight (kg) & $\begin{array}{c}0.56 \pm 0.06 \\
(8.97 \pm 0.68 \%)\end{array}$ & $\begin{array}{c}0.58 \pm 0.06 \\
(8.54 \pm 0.27 \%)\end{array}$ & $\begin{array}{c}0.61 \pm 0.05 \\
(8.60 \pm 0.48 \%)\end{array}$ & $\begin{array}{c}0.58 \pm 0.03 \\
(8.64 \pm 0.31 \%)\end{array}$ \\
\hline Flank weight $(\mathbf{k g})$ & $\begin{array}{c}0.21 \pm 0.03 \\
(3.36 \pm 0.31 \%)\end{array}$ & $\begin{array}{c}0.23 \pm 0.03 \\
(3.39 \pm 0.31 \%)\end{array}$ & $\begin{array}{c}0.25 \pm 0.06 \\
(3.52 \pm 0.73 \%)\end{array}$ & $\begin{array}{c}0.23 \pm 0.02 \\
(3.42 \pm 0.29 \%)\end{array}$ \\
\hline Brest and shank (kg) & $\begin{array}{c}1.52 \pm 0.05 \\
(24.35 \pm 0.85 \%)\end{array}$ & $\begin{array}{c}1.54 \pm 0.14 \\
(22.68 \pm 0.76 \%)\end{array}$ & $\begin{array}{c}1.56 \pm 0.08 \\
(22.00 \pm 1.35 \%)\end{array}$ & $\begin{array}{c}1.54 \pm 0.05 \\
(22.95 \pm 0.58 \%)\end{array}$ \\
\hline \multicolumn{5}{|c|}{ Edible offal (Variety Meat) (kg) } \\
\hline Liver & $0.24 \pm 0.01$ & $0.27 \pm 0.03$ & $0.29 \pm 0.03$ & $0.27 \pm 0.01$ \\
\hline Kidney & $0.04 \pm 0.01$ & $0.04 \pm 0.01$ & $0.05 \pm 0.01$ & $0.04 \pm 0.01$ \\
\hline Heart & $0.06 \pm 0.01$ & $0.05 \pm 0.01$ & $0.06 \pm 0.01$ & $0.05 \pm 0.01$ \\
\hline Spleen & $0.03 \pm 0.01$ & $0.03 \pm 0.01$ & $0.03 \pm 0.01$ & $0.03 \pm 0.01$ \\
\hline Testicle & $0.13 \pm 0.01$ & $0.13 \pm 0.01$ & $0.13 \pm 0.01$ & $0.13 \pm 0.01$ \\
\hline \multicolumn{5}{|l|}{ Non carcass components $(\mathrm{kg})$} \\
\hline Blood yield & $0.62 \pm 0.02$ & $0.64 \pm 0.04$ & $0.68 \pm 0.02$ & $0.65 \pm 0.02$ \\
\hline Head yield & $1.15 \pm 0.02$ & $1.21 \pm 0.06$ & $1.29 \pm 0.08$ & $1.22 \pm 0.03$ \\
\hline Skin yield & $1.40 \pm 0.05$ & $1.45 \pm 0.13$ & $1.56 \pm 0.14$ & $1.47 \pm 0.06$ \\
\hline Hind feet yield & $0.24 \pm 0.01$ & $0.27 \pm 0.02$ & $0.29 \pm 0.02$ & $0.26 \pm 0.01$ \\
\hline Fore feet yield & $0.25 \pm 0.01$ & $0.24 \pm 0.01$ & $0.27 \pm 0.01$ & $0.25 \pm 0.01$ \\
\hline GIT full & $4.80 \pm 0.22$ & $5.21 \pm 0.40$ & $5.47 \pm 0.44$ & $5.16 \pm 0.21$ \\
\hline GIT empty & $1.67 \pm 0.13$ & $1.72 \pm 0.20$ & $2.10 \pm 0.32$ & $1.83 \pm 0.13$ \\
\hline Lung & $0.17 \pm 0.01$ & $0.17 \pm 0.02$ & $0.18 \pm 0.01$ & $0.17 \pm 0.01$ \\
\hline Trachea & $0.04 \pm 0.01$ & $0.04 \pm 0.01$ & $0.04 \pm 0.01$ & $0.04 \pm 0.01$ \\
\hline Esophagus & $0.03 \pm 0.01$ & $0.03 \pm 0.01$ & $0.03 \pm 0.01$ & $0.03 \pm 0.01$ \\
\hline
\end{tabular}

*SWB- Slaughter Weight Basis; EWB- Empty Weight Basis 
Proportion of legs and breast and shank was comparatively higher while that of loin, rack, neck and shoulder was lower than in Kanniadu goat (Elangovan et al., loc.cit) and Barbari goat (Sebsibe and Mathur, 2000). The weight $(\mathrm{kg})$ of rack and loin in present study were in agreement with reports in Osmanabadi goat (Hakim et al., loc. cit). There was no significant difference $(p>0.05)$ found between treatments in weight of edible and non-edible offals.

Among non-edible offal, hide had the highest proportion followed by blood, fore-feet, hindfeet, lungs, testicle, trachea and esophagus. Proportions of pre-slaughter weights of nonedible parts are comparable with Kanniadu goat (Elangovan et al., loc. cit), while higher proportionally from Sirohi and Barbari goat (Das et al., loc. cit; Sureshkumar et al., loc.cit). In edible offals, the liver had the highest weight followed by heart, kidney and spleen in all the three systems of weaning.

An attempt was made to compare the carcass characteristics of Tellicherry Goat under three different systems of weaning viz. Late weaning (at three month); Mid weaning (at two month) and Early weaning (at one month). Different weaning system has no affect on the carcass traits of Tellicherry goats.

\section{References}

Das, A. K., Rajkumar, V. and Singh, S.K. (2011). Effect of litter size on growth, carcass and meat quality characteristics of barbari kids. Indian Journal of Small Ruminants, 17(1): 68-73.

Drzaic, V.B., Mioc, V. P., Prpic, Z. and Vnucec, I. (2011). The effect of slaughter weight and sex on carcass traits of Croatian Spotted goat kids. European Conference on 'Food and Nutrition in the $21^{\text {st }}$ Century' Warsaw,
Poland 8-9 September, XIII: 186-191.

Elangovan, G., Murailidharan, Ra., Tensingh Gnanaraj, P., Murugan, M. and Kumararaj, R. (2010). Carcass characteristics of kanniadu goat under different systems of management. Journal Veterinary and Animal Sciences, 4: 43-46.

Hakim, A., Karanjkar, P.L. and Karanjkar, L.M. (2005). Effect of feeding system on growth and carcass traits of osmanabadi kids. Indian Journal of Small Ruminants, 11(1): 18-23.

Hashem, A.L.S., Shaker, Y.M., Abdel-Fattah, M.S., Amer, H.Z. and Ellamei, A. M. (2013). Effect of Weaning Age on Growth Performance and Carcass Traits of Barki Lambs in Siwa Oasis, Egypt. World Applied Sciences Journal, 21 (7): 975-982.

Huiling, M., Chong, W. and Zhongtang, Yu. (2019). Weaning Ages Do Not Affect the Overall Growth or Carcass Traits of Hu Sheep. Animals, 9:356-367.

Memisi, N., Zujovic, M., Tomic, Z. and Petrovic, M. P. (2009). The effect of time of weaning on body mass and gain in kids. Biotechnology in Animal Husbandry, 25 (5-6): 993-998.

Nagpala, A. K., Singh, D., Prasad, V. S. S. and Jain, P. C. (1995). Effect of weaning age and feeding system on growth performance and carcass traits of male kids in three breeds in India. Small Ruminant Research., 17: 45-50.

Sebsibe, A. and Mathur, M. M. (2000). Effect of concentrate supplementation on carcass characteristics of stall fed Barbari kids. Indian Journal of Animal Nutrition, 1:304-310.

Singh, L. B., Singh, D. K. and Singh, C. S. P. (1994). Genetic studies on carcass characteristics of Black Bengal goats. Indian Journal of Animal Sciences, 64(2): 157-162.

Snedecor, G. W. and Cochran, W. G. (1994) 
Statistical methods, Ninth Edition, Iowa State University Press.

Sureshkumar, S., Gowane, G. R., Chopra, A. and Shinde, A.K. (2010). Growth and carcass traits of Sirohi goats under different managemental conditions. Indian Journal of Small Ruminants.
16(1): 58-61.

Ugur, F., Savas, T., Dosay, M., Karabayir, A. and Atasoglu, C. (2004). Growth and behavioral traits of Turkish Saanen kids weaned at 45 and 60 days. Small Ruminant Res,52:179.

\section{How to cite this article:}

Geetha. T., P. Tensingh Gnanaraj, U. Lakshmikantan, R. Mathivanan and Manokaran. S. 2020. Study on Effect of Different Weaning System on Carcass Characteristics of Tellicherry Goat. Int.J.Curr.Microbiol.App.Sci. 9(05): 201-205. doi: https://doi.org/10.20546/ijcmas.2020.905.023 